\title{
Using Bioretention Retrofits to Meet Virginia's New Stormwater Management Regulations: A Case Study
}

\author{
Brett A. Buckland ${ }^{1}$, Randel L. Dymond ${ }^{1} \&$ Clayton C. Hodges ${ }^{1}$ \\ ${ }^{1}$ Via Department of Civil and Environmental Engineering, Virginia Tech, Blacksburg, Virginia, United States \\ Correspondence: Brett A. Buckland, Via Department of Civil and Environmental Engineering, Virginia Tech, \\ Blacksburg, Virginia, United States. Tel: 1-540-529-3853. E-mail: bbrett08@vt.edu
}

Received: February 23, 2015 Accepted: April 4, 2015 Online Published: April 25, 2015

doi:10.5539/enrr.v5n2p135 URL: http://dx.doi.org/10.5539/enrr.v5n2p135

\begin{abstract}
Virginia's new stormwater regulations involve the use of the Runoff Reduction Method (RRM), a methodology to estimate a volume reduction in predicted runoff. Regulations require that for downstream erosion control, the product of the peak flow rate and runoff volume $\left(\mathrm{Q}^{*} \mathrm{RV}\right)$ from one-year storm events in the post-development condition be reduced to less than pre-development $\mathrm{Q}^{*} \mathrm{RV}$. This study models different bioretention sizing scenarios in a developed watershed in Blacksburg, Virginia to determine the performance at both the sub-watershed and watershed levels. In addition, models of "optimal" bioretention cells, sized to meet the RRM for each sub-watershed, are evaluated. A direct relationship is observed between the size of the cell required to meet the RRM and the sub-watershed's developed Natural Resources Conservation Service (NRCS) curve number, and a sizing analysis is provided. Modeling shows that the required size of "optimal" cells for many sub-watersheds exceeds conventional bioretention designs. Upon applying the RRM for all sub-watersheds, the resulting hydrograph at the watershed outlet more closely resembles the pre-development hydrograph than existing development.
\end{abstract}

Keywords: bioretention, stormwater management, Virginia, low impact development

\section{Introduction}

Low Impact Development (LID) is a design methodology that seeks to restore a developed site's hydrologic response to a storm to its pre-development condition (Prince George's County, 1999). Bioretention, a common LID practice, accepts runoff, allows the water to pond on top of it, and then lets water percolate through its engineered soil media to either the underlying soil or an underdrain. In Virginia, bioretention cells with an underdrain are referred to as "bioretention filters", and those without underdrains are called "bioretention basins" (DCR, 2011). Bioretention cells often utilize an outlet structure or overflow weir to allow any water in excess of the intended treatment volume that enters the cell to be routed in an efficient manner to a desired location downstream. Retrofitting urbanized areas with LID and Best Management Practice (BMP) technologies is an effective way of reducing runoff in a watershed (Damodaram et al., 2010). Although many BMPs exist that could be used in urban stormwater infrastructure retrofits, bioretention is a practice that has increasingly become attractive to designers. This study strictly focuses on the volume reduction benefits of bioretention; however, other reasons that make it a widely used practice are its high removal efficiency of nutrients and pollutants and creation of canopy and wildlife habitat for small species in urban settings.

In September 2011, the Commonwealth of Virginia's (VA) Department of Conservation and Recreation (DCR) made substantial revisions to the Virginia stormwater management regulations. Since then, authority has been transferred to the Virginia Department of Environmental Quality (DEQ), which has taken the lead in development and implementation of the regulations. These regulations were divided into two main categories: quantity and quality of stormwater runoff (DEQ, 2013). Although improvements to storm water quality and its ultimate effect on the Chesapeake Bay were a huge driving force in development of these regulations, this study deals exclusively with the stormwater quantity aspect of the regulations; specifically, those dealing with channel erosion.

The stormwater quantity regulations have changed significantly with the recent revisions, which previously required the peak developed flow rates from the 2- and 10-year storm events to be returned to the pre-development flow rates (DCR, 1999). In addressing stormwater runoff quantity, the new regulations consider channel protection and flood protection as the two primary components of interest. Discharge requirements are 
based on the type and condition of the receiving channel. When discharging into a natural conveyance system, for instance, a primary channel protection criterion requires comparison of the 1-year, 24-hour storm event's peak runoff rate and total runoff volume for both pre- and post-development conditions (VA, 2011).

To minimize erosion, the new channel protection requirements use a method that is unique to Virginia. Equation 1 (VA, 2011) is used for channel protection calculations when discharging to a natural channel. The purpose of the equation is to calculate the maximum allowable peak flow rate for the developed condition during the 1-year storm event $\left(Q_{D e v}\right)$. Rearranging the equation by multiplying both sides of Equation 1 by the developed runoff volume $\left(R V_{D e v}\right)$, yields Equation 2, where the peak flow rates $(Q)$ are multiplied by the volumes $(R V)$ of flow for the 1-year storm event for both the pre- and post-development conditions. This product is used as the basis for analysis in the rest of this study and referred to as Q*RV. Note that in Equation 2, the developed Q*RV must be less than or equal to $80 \%(I . F$.) of the pre-development $\mathrm{Q} * \mathrm{RV}$ for sites greater than 0.4 hectares, which constitutes all of the sites in this study.

$$
\begin{gathered}
Q_{\text {Dev }} \leq I . F .{ }^{*} Q_{\mathrm{Pr} e} * \frac{R V_{\mathrm{Pr} e}}{R V_{D e v}} \\
Q_{\text {Dev }} * R V_{D e v} \leq I . F . * Q_{\mathrm{Pr} e} * R V_{\mathrm{Pr} e}
\end{gathered}
$$

Where: $\quad$ I.F. (Improvement Factor) $=0.8$ for sites $>0.4$ hectares or 0.9 for sites $\leq 0.4$ hectares

$Q_{\text {Dev }}=$ peak flow rate for the developed condition 1-year storm $\left(\mathrm{m}^{3} / \mathrm{s}\right)$

$Q_{P r e}=$ peak flow rate for the pre-developed condition 1-year storm $\left(\mathrm{m}^{3} / \mathrm{s}\right)$

$R V_{\text {Dev }}=$ volume of runoff - developed condition using $R R M$ for the 1-year storm (cm)

$R V_{\text {Pre }}=$ volume of runoff-pre-developed condition for the 1-year storm (cm)

The $Q^{*} R V$ value seems to be unique to Virginia regulations, as none of the surrounding states have regulations that incorporate this value. However, several large municipalities in Northern Virginia, including Fairfax and Prince William Counties, have begun using the similar channel and flood protection criteria to the new Virginia regulations that include the Q*RV value (Fairfax County, 2014 and Prince William County, 2014). Rolband and Graziano (2012), who describe this method as the "Energy Balance" method, aided in the method's development with VA's DCR. For flood protection, calculation of the 10-year, 24-hour runoff is required to ensure that the post-development peak flow rate is at, or below, the pre-development peak (VA, 2011).

In an attempt to estimate stormwater volume reductions through BMPs, the new regulations use a tool called the Virginia Runoff Reduction Method (RRM). The RRM is used to adjust post-development curve numbers downstream of proposed BMPs. Although the use of a particular hydrologic method for calculations is not explicitly required in the regulations, the integrated computation of the curve number adjustment practically forces design engineers in Virginia to use NRCS methodology for site design, without regard to the size of the contributing drainage area. The strategies for this method were developed for Virginia by the Center for Watershed Protection (CWP) and the Chesapeake Stormwater Network (CSN) in an attempt to better emulate pre-development hydrologic conditions on the developed site (CWP \& CSN, 2008) and estimate the effects of BMPs in series. A review of the Virginia Runoff Reduction Spreadsheet shows that it incorporates a number of BMPs with varying runoff reduction and pollutant removal capabilities. One of the most efficient BMPs is bioretention. Brown and Hunt (2010) stated that bioretention improves both water quality and quantity aspects. Due to both water quality and quantity requirements in Virginia's regulations and bioretention's benefits in both of these aspects, it is likely to become more frequently implemented.

Many studies have demonstrated that bioretention is an effective means of stormwater management for both quantity and quality, especially at the site scale. Bioretention is especially effective for less intense, more frequent storm events (Davis, 2008; James and Dymond, 2012). The results of the installation of two bioretention cells in a Maryland parking lot suggest that bioretention can greatly reduce the volume of runoff, lower peak flow rates, and increase lag times (Davis, 2008). Bioretention retrofits are becoming more popular due to their hydrologic benefits. Winston et al. (2013) found a substantial reduction in runoff volume can be achieved in a developed watershed through the addition of bioretention cells along the roads, permeable pavement parking stalls, and a tree filter device. A retrofit bioretention cell installed in the Stroubles Creek watershed in Blacksburg, Virginia was shown to reduce the average peak and volume of runoff by over $90 \%$, even though its surface area is only $2 \%$ of the drainage area, which is below the recommended and commonly used percentages (DeBusk and Wynn, 2011). However, there were very few large, intense storms studied due to the timing of the monitoring. 
The location of bioretention in a watershed is critical for maximizing its efficiency. James and Dymond (2012) found that bioretention is more efficient when it is treating large impervious areas, than when it is treating areas that have a higher percentage of pervious cover. Gilroy and McCuen (2009) had similar conclusions, and also determined that installing BMPs in series compounds their effects. Proper sizing, maintenance, and construction practices are also critical to the performance of bioretention and, if designed correctly, can result in a practice that reduces both the peaks and volumes of flows leaving a site (Brown and Hunt, 2010). Li et al. (2009) studied four locations with bioretention cells in Maryland and North Carolina and found that cells with larger storage volumes, either through a larger cell area or deeper media depths, more closely replicated pre-development conditions, even for larger storms, by reducing peak flow rates, reducing outflow volumes, and promoting more infiltration. Although these studies provide insight on the functionality of bioretention cells, they do not go as far as determining what size facilities would be required to meet water quantity regulations for their respective jurisdictions.

The purpose of this study is to provide insight into bioretention sizes required to meet peak reductions as required by the channel protection criteria in the new Virginia stormwater regulations. The study is performed on a watershed in the Town of Blacksburg, Virginia for which a calibrated rainfall-runoff model was developed. Using several different modeling scenarios, various sizes of bioretention cells are modeled to simulate their retrofitted installation throughout the watershed. In addition, the "optimal" scenario is found for each sub-watershed within the watershed, so that it can meet the channel protection criteria of the RRM. Furthermore, effects of the RRM is studied at the watershed outlet for the scenario when all sub-watersheds within the watershed are meeting the requirements outlined for channel protection.

\section{Method}

The watershed modeled in this study is the "North Stroubles" watershed in Blacksburg. It is a 192-hectare watershed consisting of residential, commercial, industrial, institutional, and open space land uses in the headwaters of Stroubles Creek, a tributary of the New River. There is a flow sensor within the stream at the outlet of the watershed, near Webb Street, that is owned and monitored by the Town of Blacksburg. The flow sensor used is an Acoustic Doppler velocimeter, which measures the felocity of the flow and the flow area (as a function of stage). Upstream of the flow sensor, the watershed has been delineated into 41 sub-watersheds, or catchments, ranging from just over 0.4 hectares up to approximately 14 hectares, as shown in Figure 1 . The catchments were delineated based on key points of interest, such as ponds or intersections of major conveyances. In addition to the flow sensor, there is a rain gauge less than a mile outside of the boundary of the watershed. Flow and rainfall data measured by these devices were used for model calibration.

Virginia regulations require the volumetric sizing of bioretention facilities to be based on a composite weighted runoff coefficient which incorporates impervious, turf, and forested components of runoff. However, Virginia regulations do not require that bioretention facilities be designed to fully meet the requirements of the downstream erosion protection requirement of the regulations since it is realized that multiple BMPs may be required on site to achieve the various quantity and quality improvement goals. Therefore, strict adherence to the Virginia sizing methodology will not ensure that bioretention sized by the Virginia method will meet the downstream erosion protection goals examined in this study. Because of this, a simplified sizing methodology using a percentage of contributing drainage area has been used throughout. This technique is similar to previous Virginia methods which have correlated sizing of bioretention surface area with the percentage of upstream impervious area. This study examines a number of modeling scenarios which are summarized here for clarification and further described below.

- The existing conditions scenario is used as a base for other modeled scenarios

- The pre-development scenario is used for comparison at the watershed scale and to determine target values for design of each catchment's "optimal design" bioretention cell.

- There are four different "performance" scenarios that evaluate the performance of bioretention cells with surface areas sized as a percentage $(3 \%, 5 \%, 7 \%$, and $10 \%)$ of the contributing drainage areas. As mentioned previously, the bioretention basins are sized strictly based on upstream drainage area and are not strictly related to the impervious percentage in the sub-watershed. Because this study is focused on volumetric improvement and not water quality removal efficiency, it is believed by the authors that varying the percentage of the entire contributing drainage area may be more appropriate than varying the percentage of a single land cover (upstream impervious area).

- There are also two "optimal design" scenarios where the area percentage is adjusted such that the flow leaving the bioretention cell exactly meets the channel protection requirements of the RRM. 


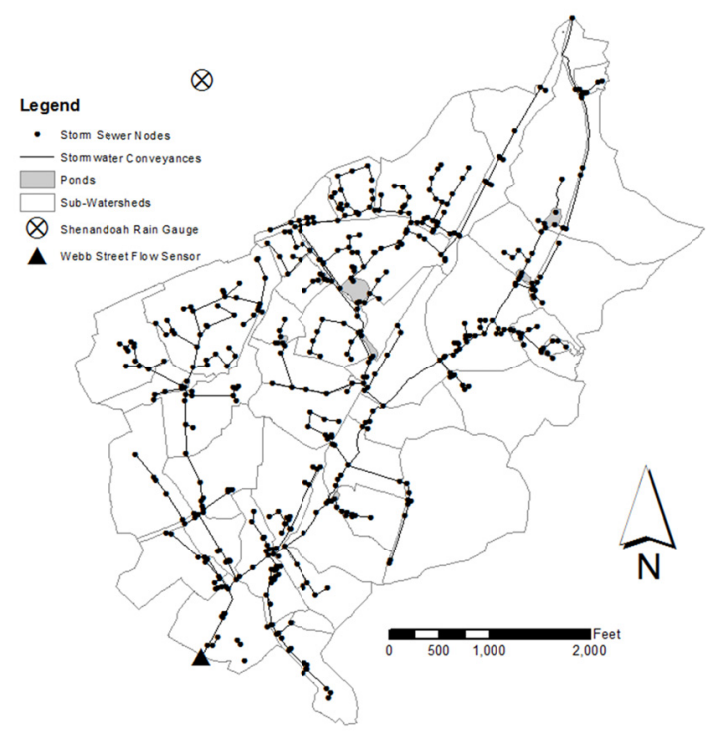

\subsection{Existing Conditions Model}

Figure 1. Study Watershed

In order to provide a baseline for comparison, the existing condition of the North Stroubles watershed was modeled and then calibrated to observed flows. One existing bioretention cell and 11 existing detention ponds are present in the watershed and were included in the model along with other existing stormwater infrastructure, such as manholes, catch basins, pond outlet structures, pipes, and open channels.

The stormwater infrastructure included in this base model is part of an ongoing partnership between the Town of Blacksburg and researchers at Virginia Tech. This infrastructure information was field collected and defined with the aid of GPS and aerial imagery. Attributes of the stormwater nodes and conveyances were entered into a Geographic Information System (GIS). Using LiDAR data, elevation and slope attributes were determined for the nodes and conveyances. The physical attributes of the infrastructure were then transferred into the SewerGEMS V8i modeling environment (Bentley, 2013), which was utilized for the hydrologic and hydraulic modeling in this study.

Data collected from the field, aerial imagery, and LiDAR data were used to delineate the sub-watersheds based on the drainage areas of the existing ponds and the intersection of major confluences within the stormwater network. Following delineation of the sub-watersheds, the modeled flows contributed by each sub-watershed were introduced at their respective downstream node located in each sub-watershed. The flows were calculated for each sub-watershed with the TR-20 (SCS, 1992) unit hydrograph methodology. Use of an NRCS methodology is required by the RRM in Virginia. After the sub-watershed flows were input, the modeling software implemented an implicit solver to route the flows downstream (Jin, 2002).

Using detailed aerial photos to assign land cover classes and the Soil Survey Geographic Database (SSURGO) (USDA, 2009), an area-weighted NRCS curve number $(\mathrm{CN})$ for each sub-watershed was produced. The high-resolution aerial imagery was digitized into land cover classes, such as buildings, asphalt, concrete, meadow, light forest, or dense forest. This information was combined with the hydrologic soil group information in the SSURGO data to produce the NRCS CN. For each sub-watershed that was delineated, a time of concentration was also determined by commonly used flow equations from the Virginia Department of Transportation (VDOT) Drainage Manual and was based on the slopes developed from the LiDAR data and the land cover data. For each sub-watershed, the most hydraulically-remote point was estimated by checking the resulting time of concentration of several possible locations along the border of each sub-watershed and selecting the longest. This process, along with other aspects of model development, is discussed in Hixon (2009) and Aguilar and Dymond (2013).

The existing conditions model was designed to mimic existing watershed conditions, so it was calibrated using data from the flow measurement device at the watershed outlet. One of the main parameters altered during the calibration process was the NRCS CN of the sub-watersheds, with calibrated values shown in Figure 2. For calibration, the $\mathrm{CN}$ for each sub-watershed was increased uniformly across all sub-watersheds, and the time of concentrations $\left(\mathrm{t}_{\mathrm{c}}\right)$ for the sub-watersheds were modified. Both changes were performed to produce more runoff, 
as it seems that the method of area-weighting the CNs resulted in underestimation of the CNs in this urbanized watershed. This was deemed necessary because the flow sensor's flow readings were much higher than those initially calculated by the model with initial estimates of $\mathrm{CN}$. With the $\mathrm{CN}$ and $\mathrm{t}_{\mathrm{c}}$ adjustments, the model was calibrated using four, single-peak storm events in 2009. These storm events were selected because they more closely replicate the single-peak nature of NRCS design storms used in the remainder of the analysis. One of the primary parameters used to calibrate the model was the difference between the measured and modeled Q*RV. This was considered a critical parameter due to a desire to meet the RRM's standards. For the selected four storm events, the differences in Q*RV between the modeled and measured values ranged from $-40 \%$ to $+21 \%$, as shown in Table 1. The other primary calibration parameter used was the Nash-Sutcliffe model efficiency coefficient (Nash and Sutcliffe, 1970), which ranged from 0.64 to 0.81 . The Nash-Sutcliffe coefficient measures the relative difference between a measured value and the modeled value compared to the measured value and the average of all of the measured values in a time series, with an ideal value of 1.0. Possible sources of discrepancies between the model and actual watershed response include errors in data collection, the effects of aggregating the parts of the sub-watersheds, or errors caused by the assumption of uniform rainfall across the watershed using precipitation data from a rain gage that is located just outside of the watershed boundary. Figure 3 shows the measured flow and the calibrated model's flow for the May 14, 2009 storm event.

Table 1. Calibration Summary

\begin{tabular}{lcccc}
\hline \multicolumn{1}{c}{ Storm Event } & $5 / 8 / 2009$ & $5 / 14 / 2009$ & $6 / 15 / 2009$ & $7 / 17 / 2009$ \\
\hline Duration of Runoff (hr) & 15.5 & 8.0 & 4.5 & 13.5 \\
Precipitation Depth (cm) & 1.9 & 2.2 & 1.3 & 2.0 \\
Time Step (hr) & 0.25 & 0.25 & 0.25 & 0.25 \\
Nash-Sutcliffe R ${ }^{2}(1970)$ & 0.78 & 0.81 & 0.66 & 0.64 \\
Measured Runoff Depth (cm) & 0.56 & 0.67 & 0.46 & 0.78 \\
Modeled Runoff Depth (cm) & 0.75 & 0.90 & 0.35 & 0.81 \\
Measured Peak Flow (m $\left.{ }^{3} / \mathrm{s}\right)$ & 2.72 & 3.54 & 2.40 & 3.17 \\
Modeled Peak Flow (m $\left.{ }^{3} / \mathrm{s}\right)$ & 2.49 & 3.12 & 1.79 & 2.49 \\
Deviation in Volume & $32 \%$ & $34 \%$ & $-24 \%$ & $4 \%$ \\
Deviation in Peak Flow & $-8 \%$ & $-12 \%$ & $-21 \%$ & $-21 \%$ \\
Deviation in Q*RV & $21 \%$ & $18 \%$ & $-40 \%$ & $-18 \%$ \\
Peak Time Shift (hr) & 0 & -0.25 & 0 & 0 \\
Model Continuity Error & $0.0 \%$ & $0.2 \%$ & $0.0 \%$ & $0.2 \%$ \\
\hline
\end{tabular}

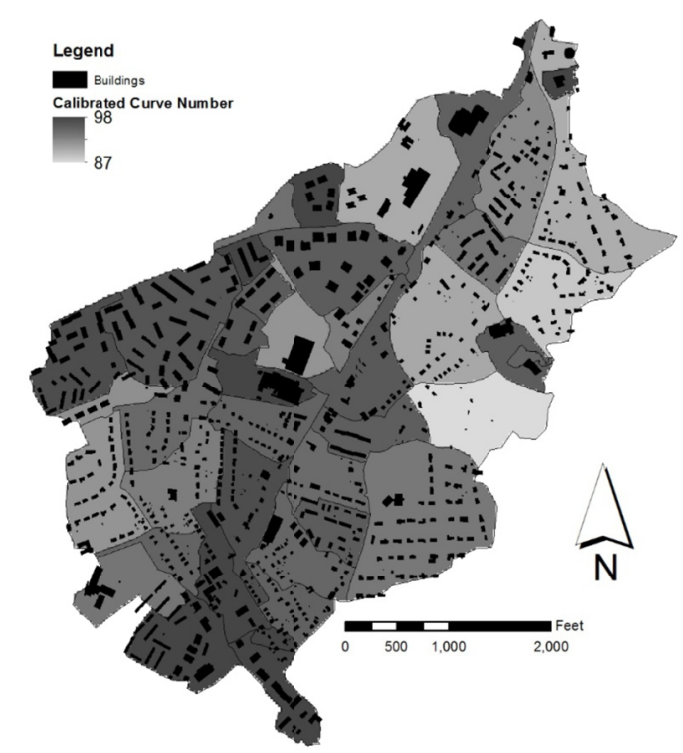

Figure 2. Calibrated Curve Numbers of Sub-Watersheds 


\section{$5 / 14 / 2009$}

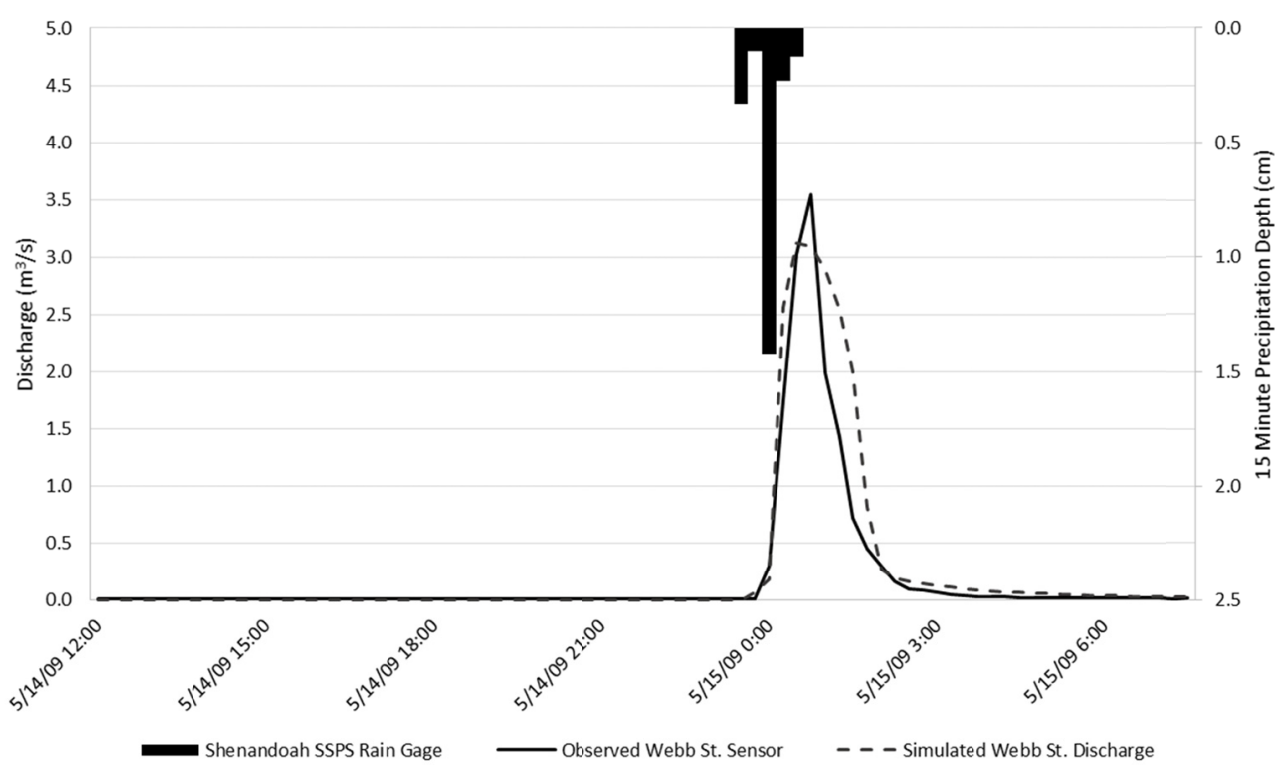

Figure 3. May 14, 2009 Storm Event

\subsection{Pre-Development Model}

In order to satisfy the requirements of the channel protection criteria, the runoff from the watershed in its developed condition must be compared to the pre-development condition. Similar to the approach in Hixon (2009), the pre-development condition was assumed as meadow in good condition with soils of Hydrologic Soil Group (HSG) C, which is considered a typical pre-development condition in the study area. This represents a CN of 71, which was distributed uniformly across the study watershed. For comparison at the watershed outlet, the entire watershed was combined into a single catchment with no man-made infrastructure, and the path used for the time of concentration assumed that the elevation of the land within the watershed remained approximately the same. For most of the analyses performed in this study, similar pre-development conditions were assumed for each of the sub-watersheds when comparisons were being made at the sub-watershed level. When analyzing the flow at the watershed outlet for the whole watershed scale, the single catchment pre-development scenario was used, as discussed above.

\subsection{Design of Bioretention Cells in Model}

The "performance" scenarios modeled the sub-watersheds with the bioretention cells sized as a percentage of the drainage area and located at the local outfall. All runoff from each sub-watershed was directed to its bioretention cell. The areas of each cell differed, but the vertical structure of the cells remained the same. Primarily, the cells were designed with $91 \mathrm{~cm}$ of engineered soil media with a porosity of $25 \%$ and then $15 \mathrm{~cm}$ of surface storage (100\% porosity), per the Level 2 Design in the Virginia Bioretention Design Specifications (DCR, 2011). The surface storage can be increased from $15 \mathrm{~cm}$ to $30 \mathrm{~cm}$, but $15 \mathrm{~cm}$ was used in this model as it is the recommended value to ensure the long term viability of the plantings within the cells. At the top of the surface storage, the weir outlet structure was designed to pass the 10-year storm for that sub-watershed. Flow entering the cell inundates the storage volume until the storage capacity is overwhelmed. Uncaptured hydrograph flow beyond the fixed storage volume exits the facility through the weir outlet structure and flows to the most downstream structure within each sub-watershed. None of the captured water in the cell reenters the modeled system, and it is assumed that it would be removed by infiltration and evapotranspiration. This modeling approach was assumed to be valid due to the high infiltration rates of the engineered soil media that is typically installed in bioretention cells and the lack of an underdrain in the design. In Virginia, the bioretention modeled in this study would be considered bioretention basins because they rely on infiltration and not an underdrain. Without an underdrain, the time that it would take the water to infiltrate into the groundwater and then return to streams as base flow would be large enough to make it insignificant to the model. Although it is not expected that infiltration would be possible in all locations, this assumption was made in order to simplify the model. In practice, soil testing would be required to determine whether an underdrain would be required. 
Since the cross-section of the cells remained uniform in the model, the variation of cell surface areas provides the means for directly calculating the changes in cell storage volume. Due to the large area of some of the sub-watersheds modeled, the cells associated with these large drainage areas are much larger than typical bioretention cells. However, it is assumed that these large cells can represent a distributed network of cells located throughout each of the sub-watersheds. Elliott et al. (2009) determined that it is acceptable to aggregate a network of bioretention cells for modeling purposes, and Gilroy and McCuen (2009) found that BMPs in series have their effects compounded regardless of the distance between them. Although the bioretention cells are designed as retrofits, they can also be implemented upon the initial development of the land.

By keeping the same vertical structure of each cell and changing the surface area, the volume of each cell is changed in a consistent manner. Since each cell only receives flow from a single sub-watershed, they were sized based on a percentage of the area of their respective sub-watershed. The four consistent percentages used for sizing the surface areas of the cells were $3 \%, 5 \%, 7 \%$, and $10 \%$ of the sub-watershed's area.

\section{4 "Optimal" Models}

Along with the sizing scenarios based solely on the percentage of the sub-watershed's drainage areas, two "optimal" scenarios were tested. The design of the "optimal" cells was achieved by adjusting the surface area for each cell until the calculated $Q^{*} \mathrm{RV}$ leaving the cell for the 1-year storm event equaled $80 \%$ of the related pre-development value. The $80 \%$ value was chosen to meet the RRM's channel protection requirements.

The first of these two scenarios maintained the typical cell's cross-section used in all other non-optimal scenarios. In the second optimal scenario, the engineered soil media depth was increased from 91 to $122 \mathrm{~cm}$. This scenario using cells of increased depth would represent an urban area where space is limited and constructing a deeper cell would be desired.

\subsection{Flood Protection Analysis}

In the RRM, the flood protection requirements call for reducing the peak flow rate from the 10 -year storm event in the developed condition back to, or below, the pre-development peak. The model was run with the 10-year storm event for the pre-development scenario, the existing conditions scenario, and the $91-\mathrm{cm}$ optimal scenario. Existing stormwater management ponds are present in the watershed and affected the flood protection analysis at the watershed outlet, but did not affect any analysis at the sub-watershed scale because the bioretention was modeled to be upstream of the pond, if present in the sub-watershed.

\section{Results}

Model scenarios were run for the 24-hour, 1- and 10-year return frequency NRCS design storm events for Blacksburg, Virginia. Rainfall depth for each storm was obtained from NOAA Atlas 14, Volume 2 (Bonnin et al., 2004) partial duration series. These values were $5.8 \mathrm{~cm}$ and $10.4 \mathrm{~cm}$ for the 24 -hour storm events for return frequencies of 1 and 10 years, respectively.

For each sub-watershed, as well as the watershed as a whole, model results were obtained for each scenario and compared to the pre-development values with respect to the peak flow rate, the volume of flow, and the Q*RV. These values were plotted against the calibrated $\mathrm{CN}$ of the sub-watershed's developed condition, as shown in Figures 4 and 5. Generally as the $\mathrm{CN}$ of the sub-watershed increased, the peak flow rate and volume of flow increased, and therefore the peak multiplied by the volume, increased as well. Also, as expected, as the area and volume of bioretention installed in each sub-watershed increased, the peak and volume of flow decreased.

When compared to the pre-development peak for the 1-year storm event, the sub-watersheds in the existing condition model ( $0 \%$ bioretention) produced peak flows between 2 and 10 times higher, as shown in Figure 4a. The 3\% scenario includes one sub-watershed which had a low $\mathrm{CN}$ and was brought below the pre-development peak, and the 5\% scenario includes five sub-watersheds achieving that reduction. Almost half of the 41 sub-watersheds in the $7 \%$ scenario had peaks at or below the pre-development value, and all of the watersheds in the $10 \%$ scenario had peak flows below the pre-development peak.

Meeting the pre-development values for volume was less successful. None of the $3 \%$, only 1 of the $5 \%$, and only 4 of the $7 \%$ sub-watersheds met the pre-development threshold (Figure $4 \mathrm{~b}$ ). Only about one-third of the sub-watersheds in the $10 \%$ scenario released less total flow than the pre-development scenario. Note that the storage volume in the $10 \%$ scenario was so large that it resulted in no flow leaving the bioretention cell for several of the sub-watersheds. 


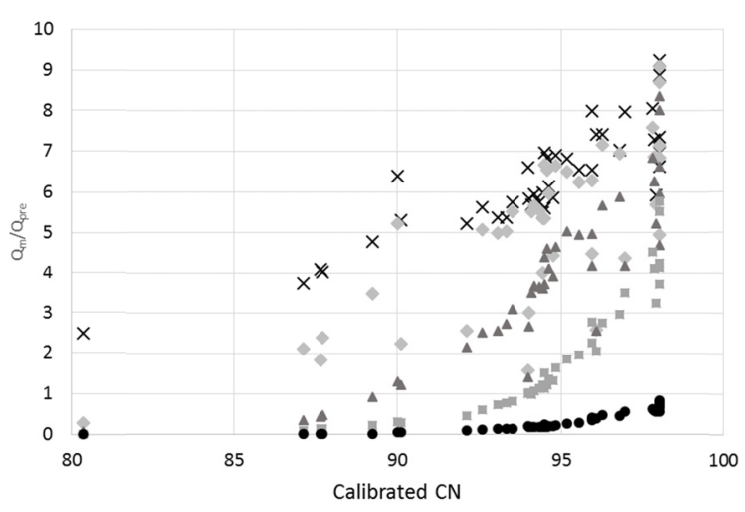

(a)

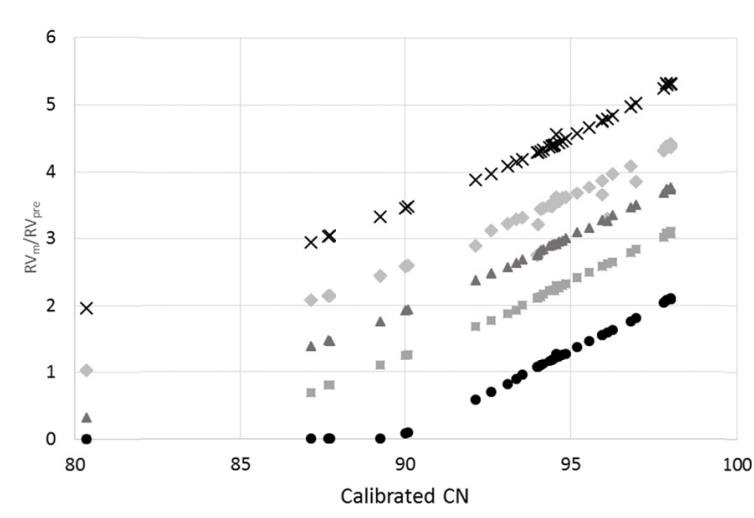

(b)

Figure 4. Comparison of Scenarios versus Pre-Development Values of Peak Flow and Volume (1-Year Storm Event)

(a) Ratio of Modeled Peak $\left[\mathrm{Q}_{\mathrm{m}}\right]$ to Pre-Development Peak [Q $\left.\mathrm{Q}_{\mathrm{e}}\right]$ vs. CN, (b) Ratio of Modeled Volume [RV $\left.\mathrm{R}_{\mathrm{m}}\right]$ to Pre-Development Volume $\left[\mathrm{RV}_{\text {pre }}\right]$ vs. $\mathrm{CN}$

When reviewing the $\mathrm{Q}^{*} \mathrm{RV}$ in Figure 5, the range of results increased greatly. Several of the sub-watersheds in the existing condition had values almost 50 times greater than those in the pre-development condition. Figure 5a shows the full range of results for the scenarios compared to the pre-development, and Figure $5 \mathrm{~b}$ shows the same information, but only for those data points below $200 \%$ of the pre-development. In the $10 \%$ scenario, $76 \%$ of the 41 sub-watersheds are below the $80 \%$ value (shown by the black line in Figure $5 \mathrm{~b}$ ) needed for the channel protection requirements of the RRM, with far fewer meeting this value in the other scenarios.

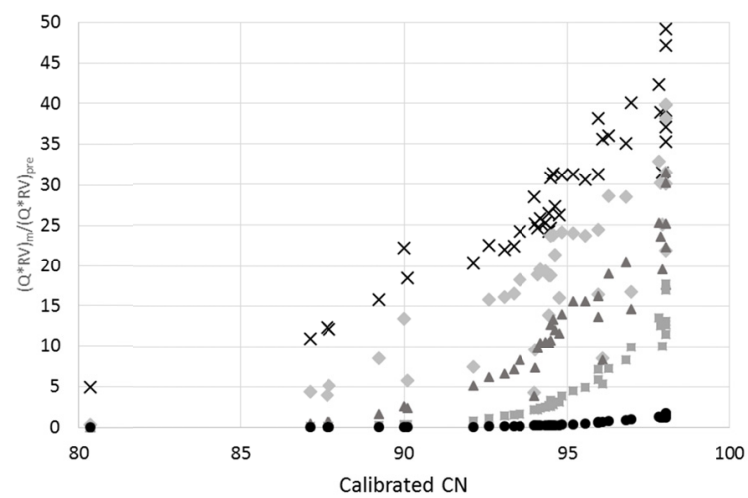

(a)

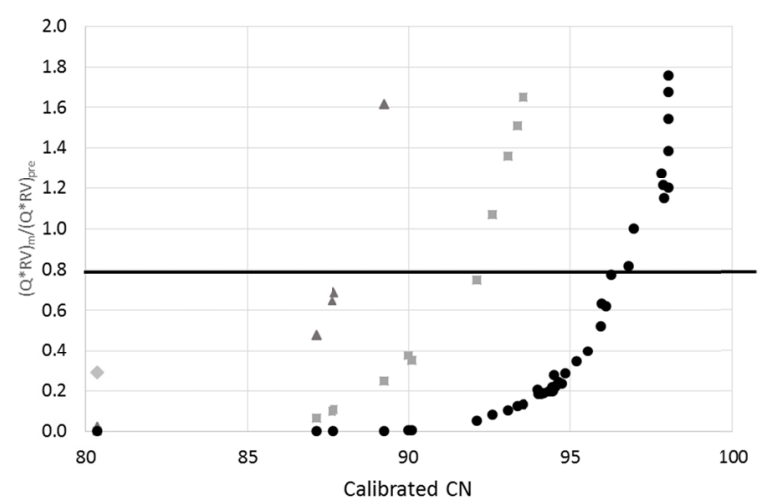

(b)

Figure 5. Comparison of Scenarios versus Pre-Development Values of Q*RV (1-Year Storm Event) (a) Ratio of Modeled Q*RV to Pre-Development $Q^{*} R V$ vs. CN, and (b) Ratio of Modeled Q*RV to Pre-Development $\mathrm{Q}^{*} \mathrm{RV}$ [under 2.0] vs. CN

The trends shown in Figures 4 and 5 demonstrate the need for a simple method of sizing bioretention based on the $\mathrm{CN}$ of the upstream watershed because of the correlation that is seen between the $\mathrm{CN}$ and the runoff metrics used in this study. There is no "one-size-fits-all" percentage that meets the requirements in a sensible way. Therefore, for each sub-watershed, the bioretention cell was iteratively sized until it met the $80 \%$ value of the Q*RV. The results of this "optimal" design for each sub-watershed can be seen in Figure 6. As expected, more area and volume of bioretention is generally needed to achieve the same results when the $\mathrm{CN}$ of the contributing drainage area is higher. Less-intensely developed sub-watersheds required cells in the range of 4-6\% of the drainage area, with moderately-developed sub-watersheds needing 7-8\% of the drainage area, depending upon the depth of the cell used. Sub-watersheds that are mostly developed required approximately 9 and $11 \%$ of their areas, based on the depth of the cells, to be used as bioretention to meet the channel protection criteria. Linear trendlines were fit to the data for both the 91- and 122-cm depths of soil media to demonstrate the approximate 
linear relationship between the $\mathrm{CN}$ of the drainage area and the required size of the bioretention cell. Other forms of regression lines had similar goodness-of-fit measures, but the simpler linear regression line was used to show the basic trend in the data since no other forms of the line have an obvious relationship between $\mathrm{CN}$ and volume of runoff. Again, for the target for the conditions in this area in this particular study, the pre-development $\mathrm{CN}$ is 71, so using the post-development $\mathrm{CN}$ and cell depth, Figure 6 could be used to size the area of a bioretention cell based on the size of the contributing drainage area.

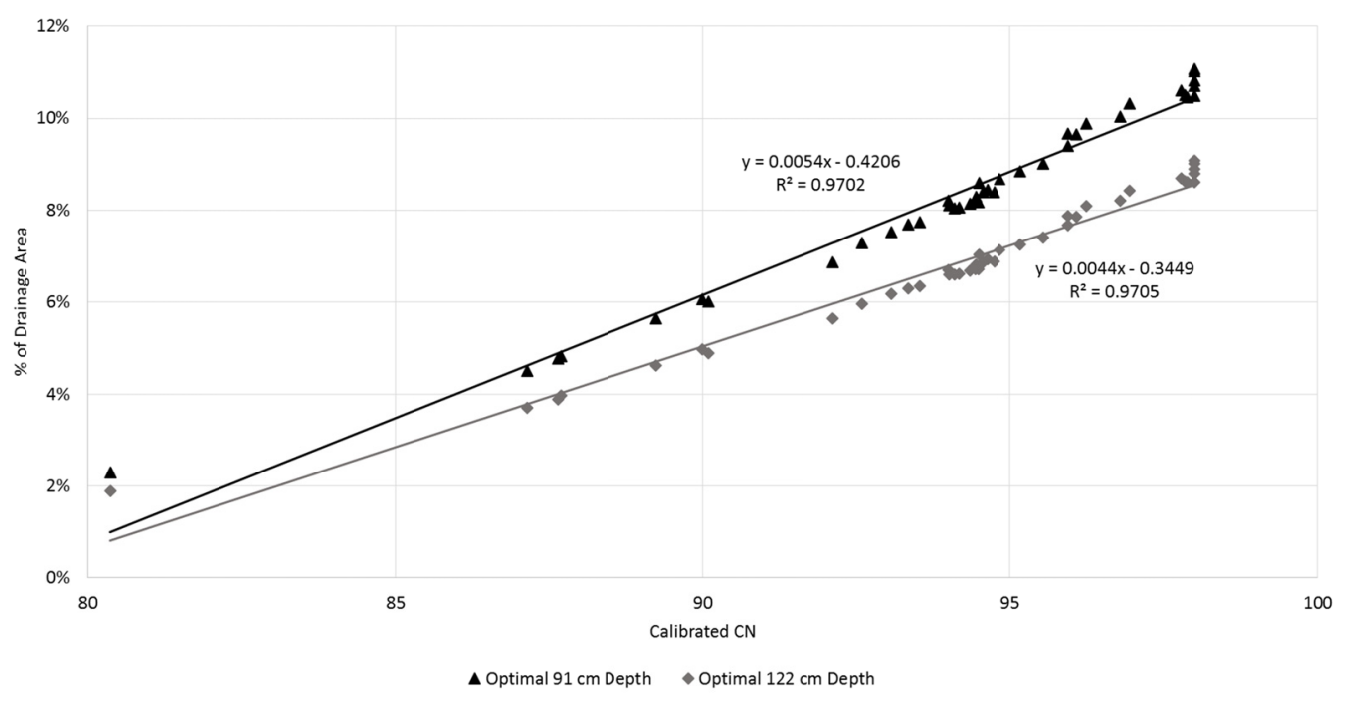

Figure 6. Optimal Bioretention Design

When increasing the depth of soil media from 91 to $122 \mathrm{~cm}$, there is a consistent drop of $18 \%$ of surface area needed for the cell for all of the sub-watersheds. Due to the design of the bioretention basins and the porosity of the media, increasing the soil media depth by $30 \mathrm{~cm}$ has the same impact on the available storage volume that increasing the surface ponding depth by $7.6 \mathrm{~cm}$ would have. Although variations in surface storage depth (typical depths are between $15 \mathrm{~cm}$ and $30 \mathrm{~cm}$ ) would more quickly affect cell storage, at an expected 4:1 ratio compared to variations in media depth, the surface ponding depth was maintained at a constant $15 \mathrm{~cm}$ across model runs because that is the preferred depth listed in Virginia DCR Stormwater Design Specification No. 9, Bioretention (2011). By design, all of the data points from both the $91-$ and $122-\mathrm{cm}$ depths meet the $80 \%$ of pre-development $\mathrm{Q} * \mathrm{RV}$ requirement. However, it is noted that the peak runoff rates and volumes of runoff for the 91- and 122-cm depths do not equal each other for any sub-watershed. The deeper cells typically have a 2-3\% higher peak with $2-3 \%$ less volume. Also, note that the size of the cell is plotted against the calibrated CN, so consideration should be given to $\mathrm{CN}$ values before using the equations for any reference or design practices.

After observing the trends in Figure 6, it was necessary to determine how the optimal cells were achieving the reduction to $80 \%$ of the pre-development Q*RV. Figure 7 shows ratios of the peak flow rates and volumes, discharging from the 91- and 122-cm deep optimal cells, to their respective pre-development values versus the $\mathrm{CN}$ of each sub-watershed. When analyzing the contributions of the peak flow rates and runoff volumes to the optimization of the cells, it is obvious that the $80 \% \mathrm{Q} * \mathrm{RV}$ was achieved primarily by peak runoff reduction. The peak flows leaving the basins averaged approximately $47 \%$ of the pre-development peak flow rates, whereas the volumes averaged approximately $170 \%$ of the pre-development volumes. The deeper cells relied slightly less on peak flow rate reduction with a relatively smaller volume increase, and as the $\mathrm{CN}$ increased, a larger relative peak flow rate reduction was necessary to meet the target.

To analyze flood protection in the watershed, the 10-year storm event was modeled for the pre-development, existing conditions, and $91-\mathrm{cm}$ optimal scenarios. The presence of the existing stormwater management facilities limits the investigation into the effects of the added bioretention on flood protection because the model results show that the existing facilities already reduce the peak flow rate in the watershed to below the pre-development peak. However, limited analysis suggests that the bioretention, installed for the purpose of channel protection, can decrease the storage required for flood protection at the sub-watershed scale by $15-20 \%$. This brief analysis was performed by comparing the volume of storage that would be required for the $91-\mathrm{cm}$ optimal and the existing conditions scenarios to reduce the peak flow from each sub-watershed to the pre-development peak for the 10 -year storm. 
A secondary goal of this study was determining the compounding effect on an entire watershed of implementing the RRM's channel protection criteria on many discrete sites within that larger watershed. The percentage scenarios, along with the existing condition, pre-development, and "optimal" scenarios, were modeled for the 1-year storm for the entire North Stroubles watershed, as well as the individual sub-watersheds. The resulting hydrographs at the outlet of the watershed can be seen in Figure 8. Applying the RRM by treating each sub-watershed as a development site (demonstrated by the optimal scenario) results in an outflow hydrograph at the watershed outlet that has a lower peak, but larger volume, than the pre-development hydrograph. Although the peak is lower than the pre-development peak, attenuation results in a descending limb that is higher than the pre-development hydrograph at the same point. Also of interest is that the application of the $10 \%$ scenario results in so much storage throughout the watershed that the hydrograph has no true peak and does not resemble a conventional hydrograph as shown in the other scenarios. Scenarios using bioretention are also noted to have shorter rising limbs then the existing condition hydrographs. This was also seen in the individual sub-watersheds and is caused by delayed runoff response caused by the cells filling up with the slower rates of runoff from the lower intensity rainfall at the beginning of the design storm and then the subsequent bypass of the additional runoff at a high rate after complete inundation of the storage volume within the cell. This also seemed to occur near the time of the higher rainfall intensity portions of the design storms used.

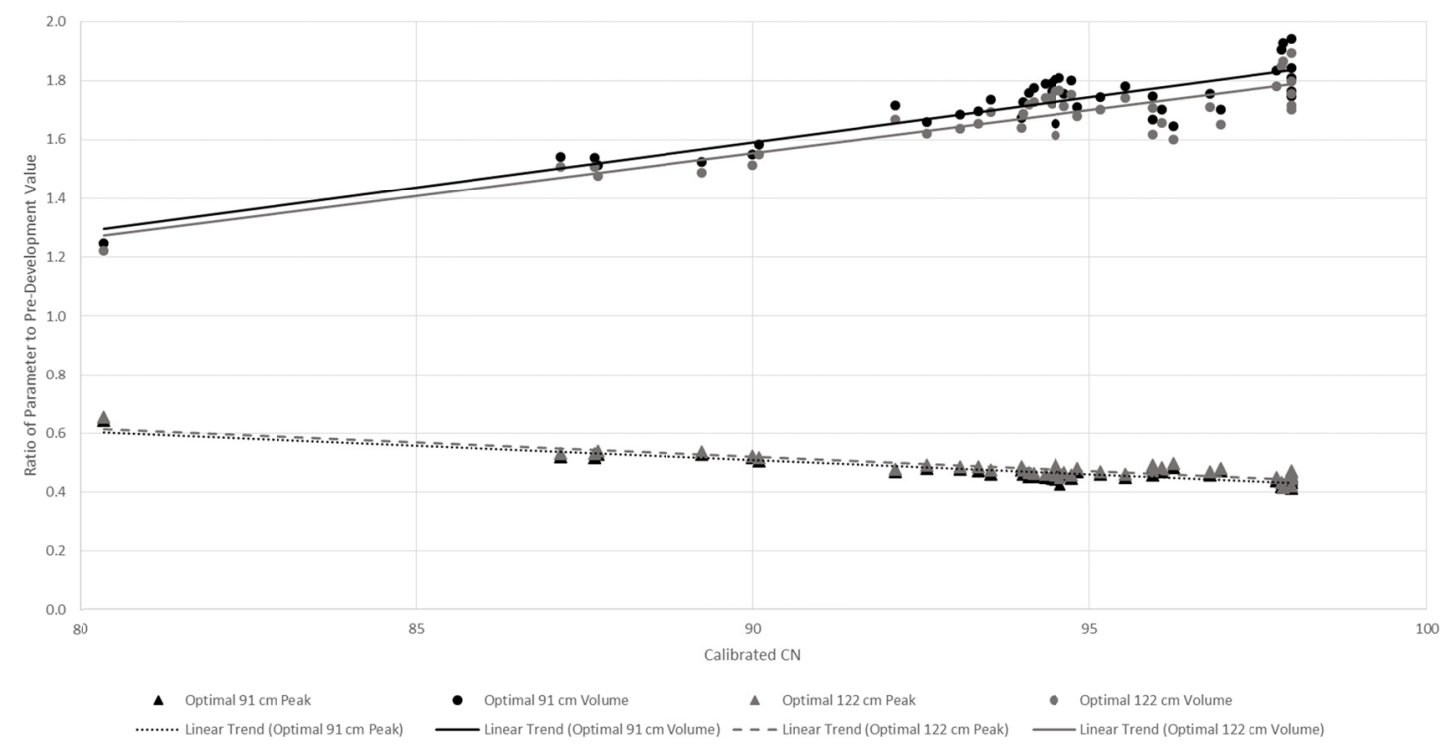

Figure 7. Ratio of Modeled Values from the Optimal Designs to the Pre-Development

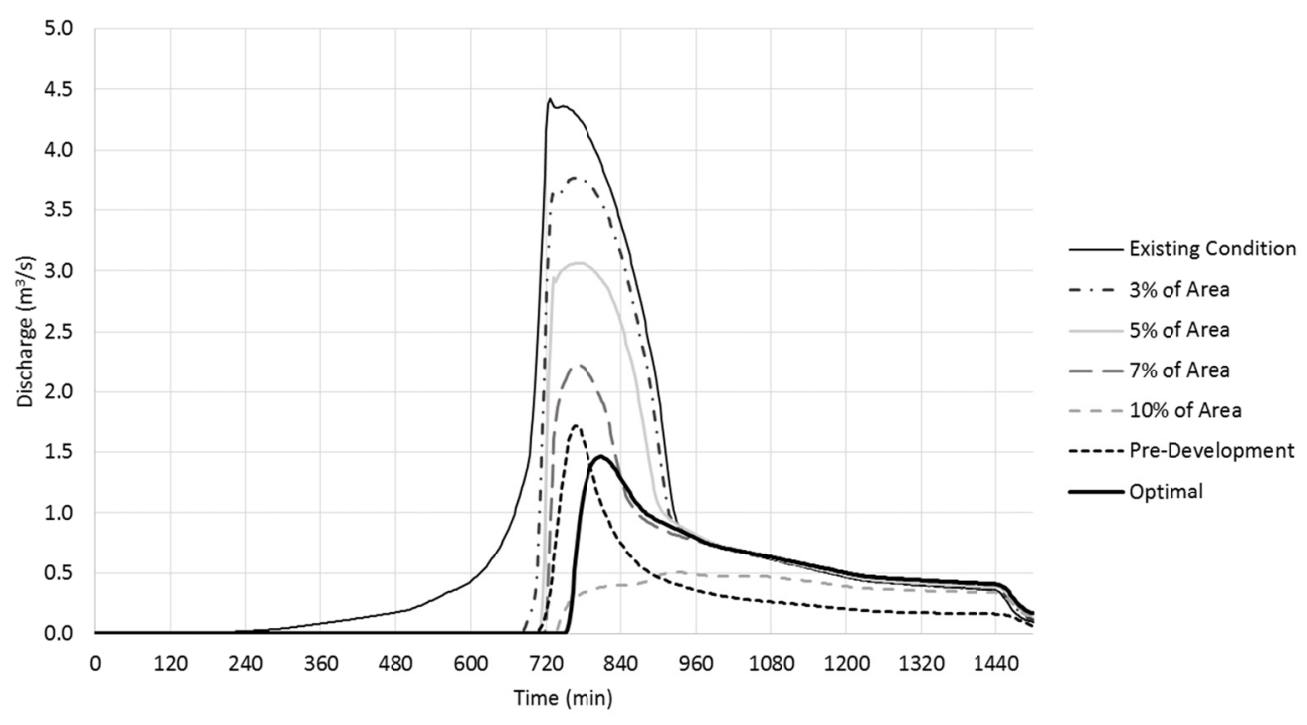

Figure 8. Modeled 1-Year Storm at the Webb Street Station 


\section{Discussion}

This study considered the channel protection criteria of the new Virginia stormwater regulations, how bioretention could be used to meet these new regulations, and the effects that implementing bioretention to meet the new regulations would have on a larger watershed scale. Bioretention cells, located at the outfall of the sub-watersheds that make up a larger, calibrated watershed model, were simulated in variable sizes as discussed previously. Resulting models yielded information regarding the effect of bioretention and overall watershed response as outlined below.

\subsection{Bioretention}

The installation of bioretention cells can result in the developed hydrology more closely mimicking the pre-development hydrology for both the site- and overall watershed-scales. All sizes of bioretention retrofits that were modeled showed decreased peak flows and volumes of flows from the developed, existing condition sub-watersheds. However, when larger percent area cells (7 and 10\%) were modeled, the flows leaving some of the cells were very small, or non-existent, which could have hydrologic ramifications on downstream receiving waters.

\subsection{Optimal Sizing}

The area, and resulting volume, of bioretention required to meet the RRM is directly related to the difference between the $\mathrm{CN}$ of the developed condition and that of the pre-development condition. As this difference increases, larger cells are needed to retain the larger amount of flow volume. The resulting sizes of the bioretention cells needed for the new standard of $80 \%$ of the $Q * R V$ are typically larger in area than those traditionally seen in practice. Due to large differences between the developed and pre-development condition, modeling indicates that some sub-watersheds require cell areas to be more than $10 \%$ of the drainage area, which is infeasible. However, these large single cells were modeled in this manner to simplify the model and, in reality, depict a distributed network of cells in the sub-watershed. As concluded in Tillinghast et al. (2012), it may be unreasonable to attempt to mimic the pre-development conditions of an intensely-developed watershed through retrofits for several reasons. The sub-watersheds with the most development, and therefore requiring larger bioretention cells, would need to have available land area to accommodate the large cells. However, based on preliminary observation, this amount of open space would not be available in many of the sub-watersheds in the area of study. In addition, the available land may not be in a location that permits the directing of runoff to the cells. Other forms of LID and BMP techniques would likely be required in this situation. In an urbanized area, the combined use of underground sand filters and underground detention can help to achieve the required water quality and quantity metrics, while limiting the impact on the surface area requirements.

\subsection{Depth Effects}

If available surface area is a major issue, modeling revealed that increasing the engineered soil media depth from $91 \mathrm{~cm}$ to $122 \mathrm{~cm}$ is a valid option. A consistent $18 \%$ reduction in area of the bioretention was shown for this change in design for meeting the regulations. This reduction was consistent across all of the sub-watersheds. Also, increasing the depth of the cells seems to result in slightly more volume attenuation, and slightly less peak attenuation. Therefore, this could be taken into account if regulations apply to either the volume or peak, but not necessarily their product.

\subsection{Watershed-Scale Effects}

Finally, the retrofit of bioretention in a watershed with the channel protection criteria results in a watershed that has hydrologic characteristics closely approaching the pre-development. When this method is applied at individual sites throughout a watershed, the modeled results at the watershed outlet are shown to result in a peak lower than the pre-development, but with prolonged flows that are somewhat higher than the pre-development levels, as shown in Figure 7. This is a substantial improvement over previous stormwater management methods that have resulted in higher peaks with longer, higher receding limbs. However, implementation of this method requires much more space for the distributed network of smaller facilities.

The sizing of bioretention cells is critical to their performance. If they are sized too small, there is little channel protection benefit in their installation, and if they are too big, the decrease in outflow for lower recurrence interval storms can be so small that it could affect the nature of the receiving waters. When sizing cells for channel protection goals, the required size is directly related to the $\mathrm{CN}$ of the contributing drainage area. However, the feasibility of the space requirements for meeting some of these goals, especially in a retrofit environment, is questionable. One possible way to overcome limitations in available area is increasing the depth of the bioretention cell, which corresponds with a decrease in the required surface area. With the RRM applied 
throughout the study watershed, the hydrograph at the watershed outlet mimicked the pre-development hydrograph much closer than the hydrograph of traditional stormwater management techniques.

\section{Acknowledgments}

The authors would like to acknowledge the Town of Blacksburg for their funding of ongoing research for urban stormwater management, as well as other members of the research team for their assistance.

\section{References}

Aguilar, M. \& Dymond, R. (2013). Innovative technologies for stormwater management programs in small urbanized areas. Journal of Water Resources Planning Management, http://dx.doi.org/10.1061/(ASCE)WR. 1943-5452.0000410 (Sep. 27, 2013).

Bonnin, G., Todd, D., Lin, B., Parzybok, T., Yekta, M., \& Riley, D. (2004). Precipitation-frequency atlas of the United States. National Oceanic and Atmospheric Administration (NOAA) Atlas 14, Vol. 2, NOAA, Silver Spring, MD.

Brown, R. A., \& Hunt, W. F. (2010). Impact of Maintenance and (Im)Properly Sizing Bioretention on Hydrologic and Water Quality Performance. Low Impact Development, 2010, 82-95. http://dx.doi.org/ 10.1061/41114(371)312.

Center for Watershed Protection and Chesapeak Stormwater Network. (2008). Technical Memorandum: The Runoff Reduction Method. Ellicott City, Maryland.

Commonwealth of Virginia. (2011). Virginia Stormwater Management Program (VSMP) Permit Regulations. Water Quantity, Virginia Administrative Code, United States.

Damodaram, C., Giacomoni, M. H., Prakash Khedun, C., Holmes, H., Ryan, A., Saour, W., \& Zechman, E. M. (2010). Simulation of Combined Best Management Practices and Low Impact Development for Sustainable Stormwater Management. Journal of the American Water Resources Association, 46(5), 907-918. http://dx.doi.org/10.1111/j.1752-1688.2010.00462.x.

Davis, A. (2008). Field performance of bioretention: Hydrology impacts. Journal of Hydrologic Engineering, 13(2), 90-95. http://dx.doi.org/10.1061/(ASCE)1084-0699(2008)13:2(90).

Department of Conservation and Recreation. (1999). Chapter 5: Engineering Calculations. Virginia Stormwater Management Handbook. Department of Conservation and Recreation, Division of Soil and Water Conservation, Richmond, VA.

Department of Conservation and Recreation. (2011). Bioretention. Virginia DCR Stormwater Design Specification No. 9. Version 1.8. Retrieved from http://vwrrc.vt.edu/swc/april_22_2010_update/ DCR_BMP_Spec_No_9_BIORETENTION_FinalDraft_v1-8_04132010.htm.

DeBusk, K., \& Wynn, T. (2011). Storm-water bioretention for runoff quality and quantity Mitigation. Journal of Environmental Engineering, 137(9), 800-808. http://dx.doi.org/10.1061/(ASCE)EE.1943-7870.0000388.

Department of Environmental Quality. (2013). Stormwater Management. Retrieved from http://www.deq. virginia.gov/Programs/Water/ StormwaterManagement.aspx.

Elliott, A., Trowsdale, S., \& Wadhwa, S. (2009). Effect of aggregation of on-site stormwater control devices in an urban catchment model. Journal of Hydrologic Engineering, 14(9), 975-983. http://dx.doi.org/ 10.1061/(ASCE)HE.1943-5584.0000064.

Fairfax County. (2014). Chapter 124 (Stormwater Management Ordinance). Code of the County of Fairfax, VA.

Gilroy, K., \& McCuen, R. (2009). Spatio-temporal effects of low impact development practices. Journal of Hydrology (Amsterdam), 367(3-4), 228-236. http://dx.doi.org/10.1016/j.jhydrol.2009.01.008.

Hixon, L. (2009). Making the case for tailored stormwater management. Master of Science thesis, Virginia Polytechnic Institute and State University, Blacksburg, VA.

James, M. B., \& Dymond, R. L. (2012). Bioretention hydrologic performance in an urban stormwater network. Journal of Hydrologic Engineering, 17(3), 431-436. http://dx.doi.org/10.1061/(ASCE)HE.1943-5584. 0000448.

Jin, M., Coran, S., \& Cook, J. (2002). New one-dimensional implicit numerical dynamic sewer and storm model. Proceedings of the 9th International Conference on Urban Drainage Global Solutions for Urban Drainage, ASCE, Reston, VA. http://dx.doi.org/10.1061/40644(2002)120 
Li, H., Sharkey, L. J., Hunt, W. F., \& Davis, A. P. (2009). Mitigation of Impervious Surface Hydrology Using Bioretention in North Carolina and Maryland. Journal of Hydrologic Engineering, 14(4), 407-415. http://dx.doi.org/10.1061/(ASCE)1084-0699(2009)14:4(407).

Nash, J. E., \& Sutcliffe, J. V. (1970). River Flow Forecasting through Conceptual Models Part I - A Discussion of Principles. Journal of Hydrology, 10, 282-290. http://dx.doi.org/10.1016/0022-1694(70)90255-6.

Prince George's County Program and Planning Division. (1999). Low-Impact Development Design Strategies: An Integrated Design Approach. Department of Environmental Resources, Prince George's County, MD.

Prince William County. (2014). Section 700 - Environmental Systems (July 1, 2014). Design and Construction Standards Manual, Land Development Division, Prince William County, VA.

Rolband, M. S., \& Graziano, F. R. (2012). The 'Energy Balance' method of stormwater management. Stormwater: The Journal for Surface Water Quality Professionals, Forester, Santa Barbara, CA, July-August 2012. Retrieved from http://www.stormh2o.com/SW/Editorial/The_Energy_Balance_Method_of_Stormwater_ Management_17718.aspx.

SewerGEMS V8i [Computer software]. (2013). Bentley Systems, Inc., Exton, PA.

Soil Conservation Service. (1992). Hydraulics and hydrology tools and models: Other models-TR-20 computer program for project formulation hydrology. Retrieved from http://www.nrcs.usda.gov/wps/portal/nrcs/ detailfull/null/?cid=stelprdb1042793.

Tillinghast, E., Hunt, W., Jennings, G., \& D’Arconte, P. (2012). Increasing Stream Geomorphic Stability Using Storm Water Control Measures in a Densely Urbanized Watershed. Journal of Hydrologic Engineering, 17(12), 1381-1388. http://dx.doi.org/10.1061/(ASCE)HE.1943-5584.0000577.

United States Department of Agriculture. (1986). Urban hydrology for small watersheds, TR-55. Technical Release 55, National Resources Conservation Service, Washington, DC.

United States Department of Agriculture. (2009). Soil Survey Geographic Database. Retrieved from http://soils.usda.gov

Winston, R., Page, J., \& Hunt, W. (2013). Catchment Scale Hydrologic and Water Quality Impacts of Residential Stormwater Street Retrofits in Wilmington, North Carolina. Green Streets, Highways, and Development 2013, ASCE, 159-172. http://dx.doi.org/10.1061/9780784413197.014.

\section{Copyrights}

Copyright for this article is retained by the author(s), with first publication rights granted to the journal.

This is an open-access article distributed under the terms and conditions of the Creative Commons Attribution license (http://creativecommons.org/licenses/by/3.0/). 